\title{
Czytanie Margalita. Wprowadzenie
}

Avishai Margalit w przedmowie do antologii tekstów Isaiaha Berlina zatytułowanej The Power of Ideas opisuje przejście tego filozofa z pozycji filozofii analitycznej na pole historii idei. Przytacza swoją rozmowę z Berlinem na temat znanego zarzutu wobec filozofii analitycznej, która ciągle szlifuje ostrze, ale nigdy nie używa go do cięcia. Margalit ukazuje ten Berlinowski zwrot w oparciu o rozróżnienie na filozofię sensu (sense) i wrażliwości (sensibility):

Filozofia sensu oparta jest na języku potocznym, przykładowo — angielskim. W tym przypadku oparta jest ona na synchronicznym języku angielskim, czyli na języku w danym przedziale czasowym. Filozof, który analizuje sens angielskich terminów, nie korzysta z historii tego języka, podobnie jak szachista, analizując pewną konfigurację na planszy, nie potrzebuje informacji o tym, jak powstała ta kombinacja. Ale w filozofii wrażliwości ważny jest historyczny (diachroniczny) wymiar języka. Można powiedzieć, że podstawową zasadą jest prawo zachowania konotacji i skojarzeń. Konotacje nie umierają, tylko łagodnie znikają w tle ${ }^{1}$.

Czy tak opisywana wolta nie jest również udziałem samego Avishaia Margalita? Ten wybitny izraelski filozof, urodzony w Afuli w 1939 roku, przez całe życie pozostaje związany z Jerozolimą oraz Uniwersytetem Hebrajskim. Wywodząc się z tradycji analitycznej, podobnie jak jego przyjaciel Isaiah Berlin, w wyjątkowy sposób łączy w swoim dziele perspektywy filozofii języka, filozofii społeczno-politycznej, etyki oraz namysłu nad bieżącymi wydarzeniami i tendencjami zachodzącymi w kulturze, społeczeństwie i polityce. „Bohaterami” Margalitowych opowieści o pojęciach - jak sam nazywa własną działalność filozoficzno-krytyczną - są między innymi: upokorzenie, przyzwoite społeczeństwo, etyka pamięci, świadek moralny, zgniły kompromis czy zdrada. Pojęcia te należą do języka potocznego, są elementami różnych nurtów filozoficznych, a jednocześnie zyskują szczególne znaczenie w książkach, artykułach i esejach Margalita.

Niniejszy numer „Prac Kulturoznawczych”, poświęcony w całości myśli Avishaia Margalita, jest kontynuacją transdyscyplinarnego seminarium „Czytanie Margalita”, w którym udział wzięli wszyscy autorzy publikowanych tu tekstów, a które prowadzone było przez Katarzynę Liszkę (Katedra Judaistyki im. T. Taubego Uniwersytetu Wrocławskiego), Michała Paździorę i Michała Stambulskiego

${ }^{1}$ A. Margalit, Foreword. The Philosopher of Sensibility, [w:] I. Berlin, The Power of Ideas, red. H. Hardy, Princeton 2013, s. XV. 
(Centrum Edukacji Prawniczej i Teorii Społecznej Uniwersytetu Wrocławskiego) w latach 2017-2018.

Na numer składają się cztery artykuły i dwa thumaczenia. Pierwszy tekst, autorstwa Katarzyny Liszki, to słownik Margalitowych pojęć — wprowadzający nas w filozofię Margalita i pokazujący węzłowe pojęcia, owych „bohaterów” jego książek. Badaczka stawia mocną tezę wskazującą na rozróżnienie na moralność i etykę jako na ramę społeczno-polityczną myśli Margalita.

Artykuł Justyny Jezierskiej jest porównawczą analizą prac pamięciologicznych Avishaia Margalita i Paula Ricoeura, w której autorka wyodrębnia trzy płaszczyzny myślenia o pamięci: etyczną, religijną i społeczno-polityczną. Zauważa również, że obaj myśliciele są „filozofami wrażliwości” w tym sensie, jaki nadał temu sformułowaniu Margalit w przytoczonym cytacie. W pojęciu ,pamięci” dostrzegają bowiem nieoczywiste, niewidoczne już, ale nadal ją kształtujące konotacje.

Filip Cyuńczyk sięga po Etykę pamięci i Przyzwoite spoleczeństwo Margalita, by zastanowić się, czy koncepcje etycznej pamięci i przyzwoitego społeczeństwa mogą być kryteriami analizy pamięci zbiorowych w Europie Środkowo-Wschodniej, czy może tworzą swego rodzaju wyzwanie etyczne, jakie powinny podjąć „młode” demokracje tej części Europy.

Czy z użyciem filozoficznej koncepcji świadka moralnego autorstwa Margalita można przeanalizować konkretne świadectwo, jakim są notatki Załmena Gradowskiego, który sporządził je w latach 1943-1944 w krematoriach Birkenau, będąc członkiem Sonderkommando? Jaka jest różnica między byciem świadkiem moralnym a świadkiem postępującym moralnie, między dawaniem świadectwa, działaniem a reprezentowaniem? Te pytania stawia w swoim artykule Marta Iwaszuk.

Numer zamykają dwa rozdziały z dwóch książek Margalita: Upokorzenie z Przyzwoitego społeczeństwa oraz Świadek moralny pochodzący z Etyki pamię$c i$, oba w tłumaczeniu Katarzyny Liszki. Mamy nadzieję, że te końcowe pozycje numeru „Prac Kulturoznawczych” będą jednocześnie początkiem wielu odczytań, dyskusji i polemik.

Dialog, do którego chcemy zachęcić czytelników i czytelniczki, jest natury interdyscyplinarnej, gdyż Avishai Margalit porusza zagadnienia z różnych obszarów, takich jak myśl żydowska, judaizm, religioznawstwo, filozofia polityczna i społeczna, psychologia, socjologia, prawo czy studia nad pamięcią. Publikując numer „Prac Kulturoznawczych” poświęcony Margalitowi, jesteśmy przekonane, że myśliciel ten ma do zaoferowania kulturoznawstwu, filozofii kultury i refleksji o kulturze inspirację zarówno teoretyczną, jak i praktyczną. Ta pierwsza zawiera się w sposobie prowadzenia badań przez Margalita (łączącego filozofię analityczną z filozofią przykładu i krytyką ideologii) oraz w rozwijanych przez filozofa koncepcjach, jak choćby upokorzenia czy etyki pamięci. Z kolei przedstawione przez Margalita przykłady i diagnozy na temat rzeczywistości kulturowej i spo- 
łeczno-politycznej są interesującym punktem wyjścia do analiz porównawczych, prób aplikacji i dalszych rozważań.

Czytanie Margalita przy użyciu kluczy interpretacyjnych zaproponowanych w niniejszym numerze „Prac Kulturoznawczych” otwiera zbiór wielu możliwości analizy i interpretacji jego dorobku. Niezależnie z jakiej perspektywy rozpoczniemy lekturę Margalita, w istniejącej sytuacji polityczno-społecznej (wzmożenia polityk pamięci, aktywacji słownika, w którym istotną rolę odgrywa zdrada i upokorzenie) potencjał tkwiący w tekstach tego filozofa wzrasta w dwójnasób. Dlatego nie tylko konwencjonalnie zachęcamy do lektury, ale raczej widzimy potrzebę wczytania się w teksty Avishaia Margalita.

Justyna Jezierska

Katarzyna Liszka 